\title{
Ilirska kapucinska provincija i put prema izboru Tomislava Šagija za provincijala 1955. godine
}

\author{
ANTo BARIŠIĆ** \\ UDK: 27-789.32-05Šagi, T. • Izvorni znanstveni rad \\ Primljeno: 12. lipnja 2017. • Prihvaćeno: 26. siječnja 2017.
}

Sažetak: U radu je istražena i predstavljena Ilirska kapucinska provincija s izborom Tomislava Šagija za njezina provincijala $i$ ono što je tome izboru prethodilo. Radi toga ukratko je načinjen osvrt na povijesni društveno-politički i crkveno-redovnički okvir unutar kojeg je provincija djelovala $i$ unutar kojeg je bio izbor Tomislava Šagija, franjevca kapucina, za provincijala Ilirske kapucinske provincije, u srpnju 1955. godine. Poslije kraćeg upoznavanja s vanjskim, izvancrkvenim prilikama tadašnjeg društva is preventivnim uhićenjem Tomislava Šagija od strane civilne vlasti, slijedi uvid u opći pregled $i$ upoznavanje s Ilirskom kapucinskom provincijom s povijesnog, statističkog $i$ upravnog gledišta. Nakon toga kratko će biti riječi o službama koje je fra To-

* Doc. dr. sc. Anto Barišić, Katolički bogoslovni fakultet Sveučilišta u Zagrebu, Vlaška 38, 10000 Zagreb, Hrvatska, anto@kapucini.hr mislav Šagi obnašao prije izbora za provincijala u razdoblju od 1949. do 1955. godine. I na kraju istražujemo pripreme za provincijalni kapitul, njegovo održavanje i prikazujemo rezultate provincijalnog kapitula koji se održao 19. srpnja 1955. godine u samostanu franjevačke male braće kapucina u Varaždinu, a na kojem je Tomislav Šagi bio izabran za provincijala Ilirske kapucinske provincije. Povod za istraživanje zadane i do sada neistražene teme 50. je obljetnica ukinuća (1967. - 2017.) nekadašnje zajedničke dvonacionalne $i$ dvojezične kapucinske provincije zvane Ilirska, sastavljene od fratara Hrvata i Slovenaca, pri čemu se autor služio isključivo do sada neistraženim arhivskim izvornim dokumentima.

Ključne riječi: Ilirska kapucinska provincija, provincijal, kapitul, fra Tomislav Šagi. 


\section{Uvod}

Godine 2017. navršilo se 50 godina od ukinuća zajedničke dvonacionalne i dvojezične provincije Male braće kapucina koja se zvala Ilirska, a koju su sačinjavali fratri kapucini iz dva slavenska naroda: Hrvati i Slovenci. Ilirska provincija franjevačke male braće kapucina ili kraće i najčešće nazivana Ilirska kapucinska provincija, a u nekim dopisima za nju možemo susresti i naziv kapucinska provincija Ilirija ili pak samo provincija Ilirija, osnovana je 1921., a ukinuta 1967. godine. U radu ćemo koristiti kraći naziv koji je uobičajen: Ilirska kapucinska provincija. Istovremeno s njezinim ukinućem Generalna uprava kapucinskog reda sa sjedištem u Rimu donijela je i odluku o nastanka dvaju samostalnih tzv. komisarijata, dviju samostalnih upravnih jedinica, hrvatske i slovenske, koje će za koju godinu (1974.) ista uprava formalno-pravno dekretom proglasiti i samostalnim provincijama. Povodom pedesete obljetnice ukinuća Ilirske kapucinske provincije te istovremeno pedesete obljetnice nastanka samostalnih provincijalnih komisarijata, hrvatskog i slovenskog, istražujemo jedan dio njezine povijesti, ono što je prethodilo izboru te sam izbor za provincijala na trogodišnji mandat (1955. - 1958.) njezinog člana, tada mladog redovnika, prezbitera i profesora fra Tomislava (Janka) Šagija (Bunića). U zagradu smo stavili njegovo krsno, civilno ime Janko i prezime njegove majke Bunić zato što u ovoj fazi života i djelovanja koje istražujemo on u svim potpisima i drugdje gotovo isključivo koristi svoje redovničko ime Tomislav i očevo prezime Šagi, dok će tek kasnije od 1960-ih godina preuzeti i majčino prezime Bunić, te će biti Tomislav Janko Šagi-Bunić i postati jednim od najistaknutijih hrvatskih teologa 20. stoljeća. Osim toga treba imati u vidu da će se, prema redovničkim običajima franjevaca kapucina njegova vremena, na službenim dokumentima često potpisivati na latinskom jeziku s redovničkim imenom i nazivom svoga rodnog mjesta: Thomislao a Brodarovec.

Cilj je ovoga istraživanja na temelju sačuvanih, do sada neistraživanih i neistraženih izvornih arhivskih dokumenata prvi put istražiti i ukratko rasvijetliti dio povijesti Ilirske kapucinske provincije te okolnosti, vrijeme, mjesto, prilike, neprilike, put prema izboru te povijesni kontekst unutar kojeg je fra Tomislav Šagi bio izabran za provincijala kao najmlađi provincijal dvojezične i dvonacionalne Ilirske kapucinske provincije. Najprije ćemo predstaviti povijesni društveno-politički i crkveno-redovnički okvir unutar kojeg je izabran za provincijala, a potom vanjske, izvancrkvene prilike i neprilike tadašnjeg društva obilježenog komunističkim, odnosno materijalističko ateističkim svjetonazorom. Zatim ćemo se ukratko upoznati s Ilirskom kapucinskom provincijom s povijesnog, statističkog i upravnog gledišta, nakon čega će biti riječi o službama koje je fra Tomislav Šagi obnašao prije izbora za provincijala u razdoblju od 1949. do 1955. I na kraju ćemo se upoznati s pripremama za provincijalni kapitul, s njegovim održavanjem i samim rezultatom kapitula 
koji se održao 19. srpnja 1955. godine u kapucinskom samostanu u Varaždinu na kojem je fra Tomislav Šagi bio izabran za provincijala.

Budući da nas od vremena provincijalne službe fra Tomislava Šagija dijeli više od šezdeset godina unutar kojih su se dogodile značajne promjene i u društvu i u Crkvi, a koje su utjecale na svu daljnju organizaciju i crkvenog (II. vatikanski sabor 1962. - 1965.) i društveno-političkog života, pad komunističkog sustava 1990. godine i potpuni raspad dotadašnje zajedničke države zvane i znane kao Jugoslavija, ukratko ćemo ukazati na vanjske prilike, odnosno na društveni i crkveni kontekst njegova vremena kao i na interne prilike same Ilirske kapucinske provincije.

\section{Povijesni kontekst}

\subsection{OdNOS KOMUNistiČKe VLASTI I KatOLIČKE CRKVE}

Razdoblje posve neprijateljskih i vrlo zategnutih odnosa novouspostavljene komunističke partijske vlasti prema Katoličkoj crkvi proteže se od 1945. godine, od završetka II. svjetskog rata kada su komunisti preuzeli vlast, pa sve do protokola između »Jugoslavije i Svete Stolice koji je potpisan 25. lipnja 1966., a zatim i uspostave potpunih diplomatskih odnosa 1970. godine. $\ll^{1}$ Vrhunac narušenih i zategnutih odnosa u tadašnjoj Narodnoj Republici Hrvatskoj između komunističke vlasti i Katoličke Crkve kulminirao je pripremama, uhićenjem, montiranim suđenjem i osudom zagrebačkog nadbiskupa Alojzija Stepinca. Za njega je sudbeno Vijeće Vrhovnog suda $\gg 11$. listopada 1946. donijelo presudu kojom ga osuđuje na 16 godina zatvora s prisilnim radom i gubitkom političkih i građanskih prava u trajanju od 5 godina. $\ll^{2}$ Komunistička je vlast odmah poslije II. svjetskog rata nastavila i s drugim raznim represivnim mjerama prema svim pripadnicima vjerskih zajednica u Državi. Dogodila su se i druga brojna namještena suđenja protiv predstavnika Katoličke crkve kao i pripadnika drugih vjerskih zajednica. Vjerske su slobode iz dana u dan bile sve više gušene i oduzimane. Komunistička je vlast zabranila $\gg$ sav katolički vjerski tisak «. ${ }^{3}$ Kakvo je bilo stanje katoličkog tiska prije II. svjetskog rata zabilježio je, među ostalim, i kroničar u kronici kapucinskog samostana u Varaždinu gdje čitamo da »od katoličkih listova kojih je prije rata bilo preko stotinu, sad izlaze dva, tj. mjesečnik 'Blagovest' i službeni mjesečni Vjesnik đakovačke biskupi-

${ }^{1}$ Z. RADELIĆ, Hrvatska u Jugoslaviji 1945. - 1991. Od zajedništva do razlaza, Zagreb, 2006., 375.376.

${ }^{2}$ M. AKMADŽA, Katolička Crkva u Hrvatskoj i komunistički režim 1945. - 1966., Rijeka, 2004., 57.

${ }^{3}$ Isto, 79. Vidi jedan dio pastirskog pisma koje autor donosi, a koje je Biskupska konferencija Jugoslavije uputila vjernicima u rujnu 1945. koji se odnosi na zabranu crkvenog tiska od strane komunističke vlasti. 
je. Obadva se tiskaju u Beogradu. $\ll{ }^{4}$ Nadalje, komunistička vlast izbacila je katolički vjeronauk iz državnih škola $\gg 31$. siječnja 1952. uputom ministra za prosvjetu NR Hrvatske. $\ll^{5}$ Jednako je tako u jeku ove komunističke anticrkvene propagande $\gg 29$. siječnja 1952. Vlada NR Hrvatske donijela rješenje kojim Katolički bogoslovni fakultet u Zagrebu prestaje biti sastavom Sveučilišta u Zagrebu. $\ll^{6}$ Komunistička vlast u smislu razbijanja crkvenog jedinstva poduzela je akciju osnutka tzv. staleških svećeničkih udruženja od kojih je »prvo osnovano u Sloveniji u srpnju 1949. na poticaj skupine svećenika i uz potporu državnih vlasti. ${ }^{7}$

Zbog svih ovih anticrkvenih poteza komunističke vlasti koji su imali za cilj nanijeti štetu i smanjiti utjecaj Katoličke crkve u komunističkom društvu došlo je i do prekida diplomatskih odnosa između Jugoslavije i Svete Stolice. Do prekida je došlo nedugo nakon što je Sveta Stolica među nove kardinale ubrojila i nepravedno osuđenog zagrebačkog nadbiskupa Alojzija Stepinca koji se u vrijeme imenovanja za kardinala nalazio u kućnom pritvoru u Krašiću. Do prekida diplomatskih odnosa između Jugoslavije i Svete Stolice došlo je $\gg 17$. prosinca 1952. $\ll^{8}$ Nakon toga, $\gg u$ razdoblju od 1953. do 1960. u odnosima između Katoličke crkve i jugoslavenske vlade nije bilo ni značajnijih sukoba ni konkretnijih poticaja za sređivanje tih odnosa. $\ll^{9} \mathrm{O}$ općem poratnom stanju netom ukratko opisanom ponešto saznajemo i od kroničara kapucinskog samostana u Varaždinu koji to stanje opisuje sljedećim riječima: »Dušobrižnički rad odvijao se normalno koliko je to bilo moguće u sadašnjim prilikama. Mise su srednje posjećivane. (...) Ima ih koje je ovo doba privelo $\mathrm{k}$ Bogu, no ima ih koji su u sadašnjoj situaciji ostavili Boga. Neki iz straha pred javnim mnijenjem (kukavičluk), neki (kako kažu) iz straha da ne izgube službu, a drugi opet jer im tako godi (opća pojava poslijeratnog doba). Stanje između Crkve i države kao i do sada. Odnosi se nisu uredili. $\ll{ }^{10}$ Kroničar i nekoliko godina kasnije konstatira neuređene odnose između Crkve i države kad kaže: »Odnos između Crkve i države još uvijek 'po starom' tj. neuređeno. ${ }^{11}$

\footnotetext{
${ }^{4}$ Kronika samostana male braće kapucina u Varaždinu za 1954. godinu. Kronika je pisana rukom i nije numerirana, a obuhvaća razdoblje od 1652. do 2009. godine. Dalje ćemo koristiti kraticu KSVŽ.

${ }^{5}$ M. AKMADŽA, Katolička Crkva u Hrvatskoj i komunistički režim 1945. - 1966., 93.

${ }^{6}$ Isto, 102.

${ }^{7}$ Isto, 105.

${ }^{8}$ Isto, 116.

${ }^{9}$ Isto, 125.

${ }^{10} K S V Z \check{z}$ za 1950. godinu.

${ }^{11}$ KSVŽ za 1954. godinu.
} 


\subsection{TOMISLAV ŠAgI PREVENTIVNO UHIĆEN}

U ovako neuređenim, nepovoljnim i napetim odnosima koji su vladali između Katoličke Crkve i komunističke državne vlasti dogodit će se izbor fra Tomislava Šagija za provincijala Ilirske kapucinske provincije. Od završetka II. svjetskog rata, od 1945. godine, pa do trenutka kad je fra Tomislav bio izabran za provincijala, do 1955., komunistička državna vlast zatvorila je, ubila, često i bez ikakva suđenja, mnoge katoličke svećenike, bogoslove, vjernike, redovnike i redovnice. Budući da se za vrijeme trajanja komunističkog režima o takvim zločinima nije smjelo ni pričati, a kamoli istraživati i pisati, takvu bilancu na vidjelo su iznijela novija znanstvena istraživanja ${ }^{12}$ koja su započela postupno odmah nakon pada komunističke diktature 1990. godine, a osobito u novijoj povijesti samostalne i demokratske Republike Hrvatske, od njezina osamostaljenja nakon referenduma u svibnju 1991. godine. Kršćanstvo se za vrijeme komunističke vladavine i diktature približilo oblicima preživljavanja kakvi su postojali u prva tri stoljeća kršćanske povijesti: progoni, zatvori i zabrane. Ono je unutar Rimskog carstva bilo zabranjena vjera na čemu se vrlo lako moglo inspirirati i novoosnovano komunističko carstvo u svim jugoslavenskim republikama koje je, kao i nekoć rimsko, progonilo, zatvaralo i zabranjivalo bilo kakvo javno tj. izvan crkveno izražavanje kršćanskih vjerskih osjećaja, dakako, vođeno drukčijim motivima (ateističkim) za razliku od onog rimskog (politeističkim).

Nekoliko mjeseci prije negoli će fra Tomislav biti izabran za provincijala, komunistička će ga vlast preventivno uhititi. U tom trenutku on je bio pomoćni i honorarni

${ }^{12} \mathrm{O}$ žrtvama i komunističkim zločinima, masovnim grobnicama u ratu i u poraću nakon II. svjetskog rata upućujemo tek na pokoju suvremenu bibliografsku jedinicu budući da je bibliografija na tu temu, zadnjih petnaestak godina, vrlo opsežna i svake se godine povećava; vidi prilog: M. AKMADŽA, Katolička Crkva u Hrvatskoj i komunistički režim 1945. - 1966., 316.-355. Akmadža donosi abecedni popis od 220 osuđenih katoličkih svećenika, časnih sestara i bogoslova na području NR Hrvatske u razdoblju od 1945. do 1951. godine; Partizanska i komunistička represija i zločini u Hrvatskoj 1944. - 1946., Z. DIZDAR, V. GEIGER, M. POJIĆ, M. RUPIĆ (ur.), Zagreb, ${ }^{32009 . ; ~}$ A. BAKOVIĆ, Hrvatski martirologij XX. stoljeća, Zagreb, 2007. Don Baković je prikupio podatke o 663 mučenika svećenika, časnih sestara i bogoslova koji su na različite načine stradali za vrijeme komunističke diktature; D. BOROVČAK, U spomen žrtvama Macelj 1945., Zagreb - Đurmanec, 2015.; O detaljnom pregledu raznih komunističkih zločina za vrijeme njihove sveukupne vladavine na teritoriju današnje Hrvatske i Bosne i Hercegovine, po pojedinim biskupijama i redovničkim zajednicama, vidi: M. BOGOVIĆ (ur.), Hrvatski mučenici i žrtve iz vremena komunističke vladavine, Zagreb, 2013. Riječ je o zborniku radova s međunarodnog znanstvenog skupa održanog u Zagrebu 24. i 25. travnja 2012. godine koji je organizirala Komisija Hrvatske biskupske konferencije i Biskupske konferencije Bosne i Hercegovine za hrvatski martirologij. Sustavnim istraživanjem komunističkih zločina preko simpozija koje organizira bavi se, među ostalim, Hrvatsko žrtvoslovno društvo utemeljeno 1991. godine u Zagrebu gdje mu je i danas sjedište. M. AKMADŽA, S. JOSIPOVIĆ BATOREK, Stradanja svećenika Đakovačke i Srijemske biskupije 1944.-1960., Slavonski Brod - Đakovo, 2012. 
nastavnik na Katoličkom bogoslovnom fakultetu Sveučilišta u Zagrebu, postavši kasnije njegovim redovitim profesorom. ${ }^{13}$ Zatim je obnašao službu provincijalnog tajnika, kapelana i magistra bogoslova. »Polovicom 1955. (točnije od 26. svibnja do 3. lipnja) u Beogradu je boravila sovjetska delegacija na čelu s N. Hruščovim. $\ll^{14}$ Taj posjet najviše sovjetske delegacije tadašnjem centru komunističke vlasti i moći u Jugoslaviji bio je povod da se tada mladog prezbitera, fratra i profesora Tomislava Šagija preventivno uhiti i zatvori, bez ikakva obrazloženja. Pretpostavljamo da je prema ustaljenoj praksi tadašnjih komunističkih sigurnosnih tajnih državnih službi, najprije $\gg$ Odjeljenja za zaštitu naroda $\ll(\mathrm{OZN}-\mathrm{e})$ pa onda $\gg$ Uprave državne bezbednosti (UDB-e), i prema njihovoj procjeni, profesor kao mladi intelektualac spadao među one koji su procijenjeni kao opasni, pa je za vrijeme trajanja posjeta ove visoke sovjetske delegacije nekoliko dana bio u pritvoru u Zagrebu. Pisanih tragova o ovom preventivnom uhićenju nismo pronašli. Međutim, kakvi su tada osjećaji i kakve misli prolazili kroz duh mladog prezbitera i profesora vidljivo je iz jedne njegove Oporuke koju je sastavio u slučaju da se iz pritvora ne vrati živ. Iz Oporuke izbija na vidjelo to kako je u tim teškim trenutcima kroz koje je prolazio pomišljao da bi mogao biti i ubijen i više se nikad ne vratiti živ. Kako bismo lakše, i barem približno, osjetili njegovo tadašnje duševno stanje i stav prema čitavoj stvari koja ga je iznenada snašla, donosimo tekst njegove Oporuke ${ }^{15}$ u cijelosti:

Kada, prijatelji, čujete da sam pao, vjerujte, da ne pustih suze zbog ovo malo

tijela, nego su svjetiljke bile užežene iako bješe smrknuto.

Žudio sam da potrošim dar života izvršivši zadatak do maksimuma u službi Onoga, koji je Dobrota - a to je onda u službi braće.

Ne mrzim i ne želim osvete onima, koji prekinuše nit, što me vezala uz cestu; jedino strepim nad prazninom ponora,

\footnotetext{
${ }^{13}$ Usp. detaljnije o ovoj fazi njegova djelovanja kod: A. BARIŠIĆ, Teandrička kristologija Tomislava Janka Šagi-Bunića, Zagreb, 2012., 22.-24.

${ }^{14}$ H. MATKOVIĆ, Povijest Jugoslavije - Hrvatski Pregled, Zagreb, 1998., 317.

${ }^{15}$ Originalni tekst Oporuke čuva se u Osobnom arhivu Tomislava Janka Šagi-Bunića koji se nalazi u samostanu sv. Mihaela male braće kapucina u Zagrebu (Donja Dubrava). Dalje ćemo koristiti kraticu $O A T J \breve{S} B$. Arhiv je trenutno u fazi sustavnog sređivanja pa ćemo za materijale koji su već sređeni i koje budemo koristili navesti i pripadajući fascikl u kojem se nalaze.
} 
koji dube u svom biću. Volio bih za njih i još jednom umrijeti.

Vi se radujte, jer znajte, da nisam pao, kao što padaju ljudi. On je bio sa mnom, koji me iz ništa izvukao i nije pustio da padnem. Premda posve nevrijedan, ja sam

Ga smio ljubiti i ne mogu ne reći, da sam sretan.

Moje papire - gdje su razasuti komadići moga srca - pokupite, prijatelji, i ako koja iskrica dirne Vaše srce, nemojte biti škrti i sebični.

Želio sam umrijeti za duše i od svih uspjeha to je najradosniji. Neka nitko ne prolije suze! Ja sam Vaš! Ja nisam pao. O kako je toplo, kad On grije na Srcu!

$\mathrm{Ti}$, brate dragi, pozdravi našu majku i oca i utješi ih, ako zaplaču, i reci im, da im je dijete umrlo, ali da nije mrtvo.

Nisam nikad znao pjevati, ali me uvijek srce sililo, jer je On, Isus - o čuda! - mene čovjeka - bez sluha izabrao među svoje pjevače!

Zato ću pjevati hvale Imenu Tvome, Višnji, moja će duša naviještati slavu Tvoju!

Amen.

Tomislav Šagi

Zagreb, 28. svibnja 1955. 
Tomislav Šagi nakon nekoliko je dana, po završetku posjeta sovjetske delegacije, bio pušten iz pritvora, ne dobivši na kraju nikakvo obrazloženje zbog čega je bio uhićen i privremeno lišen slobode premda je on na obrazloženju itekako inzistirao. Iz priče povezane s tim događajem koju je on kasnije ispričao svojoj subraći, priče koja je došla i do nas, proizlazi to da je iz pritvora bio nasilno s maramom na glavi uguran $\mathrm{u}$ auto, zatim odvezen do mjesta blizu stanovanja te izbačen iz automobila i ostavljen na ulici.

\section{Opći pregled prilika u Ilirskoj kapucinskoj provinciji}

\subsection{O STANJU I PRILIKAMA U ILIRSKOJ KAPUCINSKOJ PROVINCIJI PRIJE ŠAGIJEVA PREUZIMANJA PROVINCIJALNE SLUŽBE}

Za upoznavanje internih prilika i stanja u kojem se nalazila Ilirska kapucinska provincija od 1952. do 1955. godine, dakle, prije izbora za provincijala Tomislava Šagija, koristit ćemo se pojedinim provincijalnim izvještajima njegova prethodnika fra Alojzija Novaka. Fra Alojzije a Lopatinec (= fra Alojzije Novak), nekoliko dana prije negoli će biti izabran za provincijala početkom kolovoza 1952. godine, tada u svojstvu provincijalnog vikara, donio je, nakon kanonske vizitacije provincijala fra Odilona, Status provinciae Illyricae tempore visitationis canonicae (dalje: SPI), to jest popis svih njezinih samostana (domus formata) i hospicija u Hrvatskoj i Sloveniji od kojih se provincija sastojala te uz svaki samostan i hospicij kratak opis onoga što mu se činilo najvažnijim kao i brojčano stanje fratara u dotičnom samostanu i hospiciju. Prema SPI-u koji donosi proizlazi da je u Hrvatskoj tada bilo sedam redovničkih kuća male braće kapucina, u Varaždinu, Osijeku, Rijeci, Dubrovniku, Splitu, Karlobagu i Zagrebu. Od toga broja, prema tadašnjem crkvenom zakonodavstvu (kan. 488,5) bila su samo tri samostana koja su predstavljala tzv. domus formata: Varaždin, Osijek i Rijeka. Na čelu samostana koji je imao pravni status domus formata bio je gvardijan, a na čelu hospicija (lat. hospitium = svratište, konak), prema zakonodavstvu Reda male braće kapucina, nalazio se superior, tj. praeses ili upravitelj koji je bio » podvrgnut ili neposredno provincijalnom poglavaru ili najbližemu gvardijanu $\ll .{ }^{16} \mathrm{Da}$ bi neka redovnička kuća $\mathrm{u}$ to vrijeme mogla imati pravni status samostana, u toj je kući trebalo biti najmanje šest svečano ili doživotno zavjetovanih redovnika od kojih su najmanje četvorica istovremeno trebala biti i prezbiteri. Prema spomenutom SPI- $u$ fra Alojzija u Sloveniji je tada bilo šest kapucinskih redovničkih kuća: Škofja Loka, Sv. Križ pri Ajdovščini, Ljubljana, Krško, Maribor i

\footnotetext{
${ }^{16}$ Usp. Pravilo i Oporuka serafskoga Oca sv. Franje i Konstitucije manje braće kapucina, A. Novak (ur.), Zagreb, 1963., br. 131. Za sve daljnje navode raznih brojeva Konstitucija kapucinskog reda, ukoliko drukčije ne naznačimo, služit ćemo se ovima koje smo netom citirali jer su one bile važeće i u vrijeme o kojem pišemo.
} 
Ptuj. Od ovih šest redovničkih kuća samo su dvije imale status samostana (Škofja Loka i Sv. Križ pri Ajdovščini), dok su ostale kuće bile hospiciji. Na kraju fra Alojzije donosi i druge podatke iz kojih je vidljivo da je u tom trenutku dvojezična i dvonacionalna Ilirska kapucinska provincija, osim spomenutih pet samostana i osam hospicija, u provinciji imala: $\gg 39$ prezbitera, a izvan provincije osam; u zatvoru su bila četvorica, a u vojsci dvojica. Klerika studenata bilo je šest, u gimnaziji pet, a u vojsci 3. Fratara laika bilo je $23 . \ll 17$

Iz SPI-a kojeg donosi fra Alojzije vidljivo je nekoliko velikih poteškoća s kojima su se suočavali pojedini samostani i hospiciji, koje su odraz tadašnjih nepovoljnih društveno-političkih prilika. Civilna vlast oduzela je fratrima jedan dio samostanskog vrta u Varaždinu. U hospicijima u Dubrovniku, Splitu, Škofjoj Loki, Krškom i Mariboru civilna je vlast, ponegdje u veći (u Krškom i Mariboru), a ponegdje u manji dio hospicija, naselila njima podobne građane pa i čitave obitelji. $U$ nekim hospicijima, u Dubrovniku, Karlobagu i Mariboru, nije bilo moguće obavljati zajedničku korsku molitvu kako je propisivalo redovničko zakonodavstvo u Konstitucijama (br. 51), dok u nekima uopće nije bilo moguće imati opet Konstitucijama (br. 239) propisanu papinsku klauzuru (Maribor), a negdje se mogla održavati samo djelomično (Varaždin, Rijeka, Split, Krško, Maribor i Ptuj). Iz novosagrađene redovničke kuće, hospicija, civilna je vlast u Ljubljani izbacila fratre koji su jedno vrijeme morali stanovati kod manje braće opservanata. Jednaka je sudbina stigla fratre u kapucinskom hospiciju u Ptuju. I oni su po naredbi civilne vlasti bili izbačeni iz svoje kuće pa su privremeno stanovali kod dijecezanskih prezbitera. Materijalno stanje unutar pojedinih samostana i hospicija moglo je biti izrazito teško, osobito u Sloveniji, jer fra Alojzije u SPI- $u$ navodi da je $\gg$ našima u Republici Sloveniji zabranjeno skupljati milostinju u crkvi, osim u Ljubljani gdje se vrlo kratko vrijeme dozvoljava skupljati milostinju. $\ll^{18}$

Ono što nam je iz SPI- $a$ vidljivo jest, među ostalim, i činjenica da su fratri bili angažirani i u pastoralnom radu. U to vrijeme Ilirska kapucinska provincija imala je nekoliko župa koje su vodili njezini redovnici i to u Zagrebu, Rijeci, Karlobagu, Škofjoj Loki i Mariboru. U ostalim mjestima gdje su bili prisutni, a gdje nisu vodili ili upravljali župom, povremeno su, uglavnom u ispovijedanju, pomagali dijecezanskim prezbiterima.

${ }^{17}$ Usp. Status provinciae Illyricae tempore visitationis canonicae A. D. 1952., Varasdini 26. VII. 1957., 2., potpisan Aloysius a Lopatinec, vic. prov., u: Arhiv Hrvatske kapucinske provincije sv. Leopolda Bogdana Mandića. Za taj arhiv dalje ćemo koristiti kraticu AHKPZG. Arhiv nije posve sređen i nalazi se u samostanu sv. Leopolda Bogdana Mandića u zagrebačkoj Gornjoj Dubravi gdje je i sjedište provincijalata. SPI je pisan strojopisom na latinskom jeziku i sadrži dvije stranice teksta.

${ }^{18}$ In Republica SLOVINIAE nostratibus prohibetur eccipete ellemosinam in ecclesia, praeterquam in Ljubljana ubi aliquando ad brevissimum tempus praemittitur colligere ellemosinam. (Isto.) 
Petogodišnji izvještaj naziva De Religione et ejusque Regimine (dalje: PIAL) izvještaj je o stanju i prilikama u Ilirskoj kapucinskoj provinciji, koji su prema Dekretu Svete kongregacije za redovnike od 9. srpnja 1947. (AAS 40 [1948.] 378) provincijali trebali slati Svetoj Stolici. Kao provincijal fra Alojzije poslao je jedan takav izvještaj za razdoblje od 1948. do kraja 1953. godine. U njemu pronalazimo ono o čemu smo ukratko saznali i iz SPI-a. ${ }^{19}$ Ali PIAL je daleko opširniji pa prema tome može dati još bolji uvid u stanje i prilike u kojima se nalazila Ilirska kapucinska provincija.

Po završetku kanonske vizitacije Ilirske kapucinske provincije koju je vizitirao tadašnji provincijal fra Alojzije, iz njegova Izvještaja od 2. 12. 1954. godine vidljive su jednake poteškoće u provinciji koje smo već ranije upoznali iz njegovih prethodnih izvještaja, iz SPI- $a$ i iz PIAL-a. Od novosti i promjena koje pronalazimo u Izvještaju iz 1954. izdvajamo neke. U tom trenutku provincija je $\gg$ u pet samostana i 8 hospicija imala 45 svećenika i 21 fratra laika; jednog svećenika u zatvoru; jednog svećenika i više klerika u vojci; u novicijatu je bilo pet klerika i dva fratra laika. $\ll^{20}$ Nadalje, provincijal spominje određene ekonomske poteškoće te daljnje oduzimanje pojedinih samostanskih vrtova od strane civilne komunističke vlasti. Oduzimanje dijelova ili čitavih samostanskih vrtova (zemlje) s kojim se provincija suočavala odraz je tadašnjih komunističkih zakona o tzv. Agrarnoj reformi i njihova provođenja koje je pogađalo sve crkve, a najviše Katoličku. Tako je »svim crkvama u Hrvatskoj oduzeto oko 73119 jutara zemljišta, a najviše Katoličkoj crkvi. (...) Katolička crkva agrarnom je reformom toliko osiromašila da je njezino daljnje funkcioniranje ovisilo prvenstveno o pomoći njezinih vjernika. $\ll{ }^{21}$ Stavka o oduzimanju zemljišta i teškom ekonomskom stanju u provinciji bit će trajno prisutna u izvještajima i svih kasnijih provincijala.

Profil Ilirske kapucinske provincije kakav je dijelom vidljiv iz SPI-a, Izvještaja i PI$A L-a$, u bitnome će ostati nepromijenjen i u trenutku kad fra Tomislav Šagi bude izabran za provincijala.

${ }^{19}$ O klauzuri (217), braći laicima (20), ekonomskim poteškoćama (123), o nastanjenim civilnim osobama u pojedinim samostanima i pomoćnicama (217) vidi: Petogodišnji izvještaj provincijala fra Aloysi a Lopatinec, datiran, Varaždin, 12. XII. 1953., 9. Izvještaj je na latinskom jeziku, pisan strojopisom, sadrži 13 stranica teksta, s 442 odgovora na isto toliko pitanja iz formulara koji je sastavila generalna uprava. Brojevi u zagradama označavaju pojedinu točku izvještaja pod kojom se govori o dotičnoj temi. Izvještaj su potpisala i sva četiri definitora. Za Izvještaj ćemo dalje koristiti kraticu PIAL.

${ }^{20}$ Usp. Relatio de peracta visitatione canonica provinciae Illyricae Anno Domini 1954., pod br. 64/1964., Zagreb, 2. XII. 1953., 1, potpisuje fr. Alojsi Novak a Lopatinec, u: GA, G67. Izvještaj sadrži dvije strojopisne stranice na latinskom jeziku.

${ }^{21}$ Z. RADELIĆ, Hrvatska u Jugoslaviji 1945. - 1991. od zajedništva do razlaza, Zagreb, 2006., 189. 


\subsection{ILIRSKA KAPUCINSKA PROVINCIJA: STATISTIČKI, POVIJESNO I UPRAVNO}

Ilirska kapucinska provincija bila je sastavni dio kapucinskog franjevačkog Reda koji se od 1528. godine, kada je izrastao iz reforme kao jedan od samostalnih franjevačkih redova, proširio po svim kontinentima i svoju prisutnost, početkom 20 . stoljeća, potvrdio u više od šezdeset zemalja svijeta, a danas u preko sto. Statistički gledano franjevački Red male braće kapucina, primjerice, 1928. godine imao je sveukupno 11454 fratara u svijetu. ${ }^{22}$ Prema kasnijoj statistici i vremenu unutar kojeg se nalazi Ilirska kapucinska provincija, kapucinski se Red u svijetu još znatnije proširio i povećao za čak nekoliko tisuća članova. Tako nam statistika iz 1963. godine donosi podatak da je u svijetu na kraju te godine bilo sveukupno 15751 fratara kapucina. ${ }^{23}$ Franjevački kapucinski Red s vremenom je izrastao u jedan od najvećih redova u Katoličkoj crkvi. Danas, na početku 21. stoljeća, brojčano se stanje Reda drastično smanjilo i smanjuje se, osobito na Zapadu, te se približilo broju kakav je bio početkom 20. stoljeća. Prema novijim statistikama kapucinskog reda, brojno stanje Reda 1. siječnja 2012. godine iznosilo je 10364 kapucinskih redovnika u svijetu. ${ }^{24}$

Ilirska kapucinska provincija pravno je bila utemeljena tri godine nakon formiranja zajedničke države zvane Kraljevina Srba, Hrvata i Slovenaca (SHS) koja je »proglašena 1. prosinca 1918. godine. $\ll{ }^{25} \mathrm{Na}$ ruševinama stare dvojne političke monarhije Austro-Ugarske nastale su nove države, ali i nove redovničke provincije, a ukinute stare. Ukinućem Štajerske provincije male braće kapucina istovremeno je ostvareno osnivanje Ilirske i drugih provincija. To je učinjeno Dekretom tadašnjeg generalnog ministra reda male braće kapucina fr. Josepha Antoniusa a S. Joanne in Persiceto, koji je izdan nakon Rescripta Svete Stolice (Kongregacije za redovnike) od 11. listopada 1921., koji se spominje na početku Dekreta. Dekretom koji je da-

${ }^{22}$ Za statistiku na dan 31. 12. 1928. usp. Descriptio geographica et statica provinciarum et missionum ordinis fratrum minorum s. Francisci Capuccinorum, izdala generalna kurija kapucinskog Reda u Rimu 1929., 46.-47.

${ }^{23}$ Za statistiku na dan 31. 12. 1963. usp. službeno glasilo kapucinskog Reda koje izdaje generalna kurija i za koje odgovara tadašnji generalni ministar p. Clementin a Vlissingen, u: Analecta Ordinis Fratrum Minorum Capuccinorum, Vol. 80, Fasc. 3 (Supplementum), Romae, 1964., 16.

${ }^{24} \mathrm{Za}$ statistiku na dan 1. 1. 2012., usp. Brojčano stanje reda, u: Vjesnik Hrvatske kapucinske provincije sv. Leopolda Bogdana Mandića XLVII. (XVI.) (2012.) 2 (5), 2012., 240.-241. Najnovija pak statistika s datumom od 31. 12. 2015. može se pronaći na službenim web stranicama reda male braće kapucina na ovoj poveznici: https://www.ofmcap.org/en/cappuccini/statistica/statistica-2015 (7. 2. 2017.).

${ }^{25}$ H. MATKOVIĆ, Povijest Jugoslavije - Hrvatski pregled, Zagreb, 1998., 63. 
tiran $\gg 30$ Decembris $1921 . \ll{ }^{26}$ ukinuta je stara Štajerska provincija koju je osnovao venecijanski fratar kapucin sv. Lovro Brindiški, kasnije crkveni naučitelj, »die 10. Augusti a. $1600 \ll{ }^{27}$, te se osniva, među ostalim, i Ilirska kapucinska provincija. Iz Dekreta je vidljivo da su iz bivše Štajerske provincije novoutemeljenoj Ilirskoj kapucinskoj provinciji pripojeni slovenski samostani u $\gg$ Celju, Krškom i Škofjoj Loki, te hospiciji u Osijeku i Studencima. ${ }^{28}$ Što se tiče samostana i hospicija u Hrvatskoj od dotadašnjeg samostalnog tzv. hrvatskog komisarijata dio nove provincije prema Dekretu bit će svi dotadašnji samostani koji su činili dotadašnji komisari$\mathrm{jat}^{29}$, i to samostan u $\gg$ Varaždinu te hospiciji u Karlobagu, Splitu i Dubrovniku. $\ll^{30}$ Drugi samostani, opet prema Dekretu, bivše Štajerske provincije slovenskog dijela $\mathrm{u} \gg$ Gorici i Sv. Križu kod Ajdovščine pripali su novoosnovanoj Bečkoj provinciji male braće kapucina dok je kapucinski samostan kao dio hrvatskog dijela provincije u Rijeci bio ispočetka pod upravom Svete Stolice $\ll^{31}$, a $\gg$ kasnije je pripojen Venetskoj kapucinskoj provinciji $\ll^{32}$ Nakon II. svjetskog rata najstariji kapucinski samostan u Hrvatskoj, onaj u Rijeci, Venecijanska kapucinska provincija, pod čijom je upravom do tada bio, vratila je pod upravu Ilirske kapucinske provincije. Ilirska kapucinska provincija nakon dozvole tadašnje Svete kongregacije za redovnike ukinuta je 1967. godine Dekretom generalnog ministra kapucinskog Reda fr. Clementinusa a Vlissingena $\mathrm{i} \gg$ namjesto nje su osnovana dva provincijalna komisarijata, slovenski i hrvatski ${ }^{33}$

${ }^{26}$ Usp. GA, G50.II., 4. Decretum sadrži četiri stranice teksta i pisan je rukom latinskim jezikom, a potpisao ga je p. Melchior a Benisa, generalni prokurator i tajnik.

${ }^{27}$ Usp. Origo et Vicissitudines Almae Provinciae Styriae, u: SHEMATISMUS FF. Ordinis Minorum Sancti Patris Francisci Capuccinorum Alme Provinciae Styriae, Graecii (Graz), 1917., 7.

${ }^{28}$ GA, G50.II., Decretum, 2. Za kratak pregled, od početka do kraja, o stanju i prilikama svih samostana i hospicija slovenskog dijela koji su bili u sastavu Ilirske kapucinske provincije, o srednjoškolskom i teološkom obrazovanju, novicijatu i pastoralnom djelovanju vidi: V. ŠKAFAR, Kapucini na slovenskem v Jugoslovanski Ilirski provinci (1921-1967), u: Letopis slovenske kapucinske province, V. Kolenko, P. Kovač, M. Kvas, Š. Kožuh, M. Štravs (ur.), Ljubljana, 1996., 71.-90.

${ }^{29}$ Prema tada važećem redovničkom zakonodavstvu koje je sadržano u Konstitucijama male braće kapucina, kapucinski je Red, upravno gledano, bio podijeljen na provincije i komisarijate. »Universus Ordo noster, quoad regimen, in provincias et comissariatus dividitur $\ll$, u: Regula et Testamentum Seraphici Patris s. Francisci et Costitutiones Fratrum Minorum Capuccinorum (Editio altera), Romae, MCMXXXI, VIII. 130.

${ }^{30}$ GA, G50.II., Decretum, 2.

${ }^{31}$ Isto.

${ }^{32}$ Usp. Origo Provinciae Ordinis Minor. Cap. Illyricae, u: SHEMATISMUS F. F. Ordinis minorum S. P. Francisci Capucinorum Provinciae Illyricae, Celejae, 1925., 6. U Shematizmu pronalazimo iste podatke koje autor koristi iz Dekreta na koji smo se referirali.

${ }^{33}$ Usp. Decretum quo Provincia nostra Illyrica supprimitur, eiusque loco duo Commissariatus provinciales, Slovenicus et Croaticus, eriguntur, 1. To su naslovne riječi Dekreta kojeg je potpisao generalni mini- 
Prvo sjedište novoosnovane Ilirske kapucinske provincije male braće kapucina bilo je u Sloveniji, u Celju, a prvi od generalne uprave kapucinskog Reda imenovani provincijal bio je Slovenac $\gg$ A. R. P. Donat a s. Vid $\ll .{ }^{34}$ Prema prvom Shematizmu Ilirske kapucinske provincije iz 1925. godine, provincija je tada imala $\gg$ sveukupno 91 fratra u 6 samostana i 4 hospicija. $\ll{ }^{35}$ Brojčano stanje provincije između dva svjetska rata znatno je i postupno raslo što je vidljivo iz prethodno navedenih statistika kao i iz shematizama koje je izdavala, uređivala i odobravala aktualna provincijalna uprava. Osim sačuvanih shematizama o brojčanom stanju provincije saznajemo i iz tzv. knjižica koje su donosile Status provincije u kojem nalazimo detaljan popis samostana i hospicija po provinciji kao i imena i prezimena redovnika prezbitera i redovnika braće laika. Tako je prema Statusu Ilirske kapucinske provincije iz 1932. godine provincija imala sveukupno $\gg 8$ samostana i 2 hospicija u kojima je živjelo sveukupno 126 fratara od kojih 53 svećenika, 18 studenata klerika, 3 klerika novaka, 48 fratara laika i 4 fratra laika novaka. $\ll{ }^{36}$ Gotovo jednaku statistiku pronalazimo i u Shematizmu iz 1933. godine s tim da se broj fratara smanjio tek za jedan. ${ }^{37}$ Četiri godine kasnije prema Statusu personalis provincije iz 1937., pronalazimo da je broj fratara porastao na brojku 150 što je do sada maksimalno u kratkoj povijesti zajedničke provincije dvaju naroda. $U$ osam samostana i dva hospicija te godine bilo je $\gg 50$ prezbitera, 40 klerika, 4 studenta ter., 56 laika. $\ll^{38}$ Dvije godine kasnije broj fratara u provinciji i pred sam početak II. svjetskog rata nešto se smanjio pa je 1939. godine brojčano stanje provincije izgledalo ovako: »Sveukupan broj fratara bio je 126. Od toga je bilo 52 svećenika unutar provincije i 5 izvan provincije, klerika 19, laika $50 . \ll^{39}$

star Reda male braće kapucina fr. Clementinus a Vlissingen, Romae, in Curia nostra generali, die 21 mensis Iulii, festo s. Laurentii Brundisini, anno 1967. Dekret je strojopisan na dvije stranice teksta i nalazi se u: GA, G50, 2.1.

${ }^{34}$ GA, G50.II., Decretum, 3.

${ }^{35}$ Usp. Origo Provinciae Ordinis Minor. Cap. Illyricae, u: SHEMATISMUS F. F. Ordinis minorum S. P. Francisci Capucinorum Provinciae Illyricae, Celejae, 1925., 18.

${ }^{36}$ Usp. Status Provinciae Illyricae Ordinis minorum Capuccinorum Anno Domini MCMXXXIII ineunte editus, Osijek, 1932., 15.

${ }^{37}$ Usp. SHEMATISMUS FF. Ordinis minorum S. P. Francisci Capuccinorum Provinciae Illyricae, Celejae (Celje), 1933., 20.

${ }^{38}$ Usp. STATUS PERSONALIS Provinciae Illyricae ordinis Minorum Capuccinorum pro anno Domini 1937. Ova statistika provincije nalazi se otisnuta na jednom listu papira nešto malo većeg od današnjeg A3 formata. Status kao i svi shematizmi koje koristimo nalazi se u OATJŠB. Provincijalni ministar u to vrijeme bio je P. Odilo a Cerknica.

${ }^{39}$ Usp. SHEMATISMUS Provinciae Illyricae Ordinis minorum capucinorum, Domžale, 1939., 23. 
U jeku II. svjetskog rata Ilirska kapucinska provincija pretrpjela je značajne gubitke, osobito slovenski dio provincije jer su Slovenija i područje sjeverno od rijeke Save, nakon što je Njemačka okupirala dijelove Jugoslavije, bili priključeni njemačkom Reichu. U kronici kapucinskog samostana u Varaždinu kroničar bilježi da je »počelo čišćenje Slovenije od Slovenaca - naročito inteligencije. $\ll^{40}$ Shematizam iz 1942. godine navodi da su $\gg$ ratne godine 1941. kapucinski fratri bili protjerani iz slovenskih samostana u Celju, Škofjoj Loki, Ptuju, Mariboru i Krškom. ${ }^{41}$ Statističko stanje Ilirske kapucinske provincije ratne 1942. godine izgledalo je sada ovako: »3 samostana, 4 hospicija u kojima je živjelo 63 svećenika, 13 klerika studenata, 6 klerika novaka, 47 zavjetovanih laika, tercijara 1, iz provincije Brixen 1 svećenik, sveukupno 131 redovnik. $\ll{ }^{42}$ Nakon Shematizma iz 1942. godine nastat će po tom pitanju praznina sve do 1958. kada ga je na kraju svoga trogodišnjeg provincijalnog mandata dao izraditi provincijal fra Tomislav Šagi. Kroničar u Varaždinu donosi nam i omjer redovničkih zvanja po nacionalnosti, pri čemu navodi da je 1941. godine u provinciji bilo $\gg 44$ slovenska svećenika, 22 hrvatska i 2 njemačka. Bilo je 33 slovenska brata laika i 16 hrvatskih. $\ll{ }^{43}$

Od utemeljenja Ilirske kapucinske provincije male braće kapucina pa sve do 1952. godine, dakle kroz trideset godina, njezini su provincijali, kako shematizmi pokazuju, bili iz slovenskog dijela provincije. ${ }^{44}$ Sveukupno je provincijalnih kapitula u Ilirskoj kapucinskoj provinciji do izbora fra Tomislava Šagija za provincijala bilo šest i svi su, kako shematizam pokazuje »od 1921. do 1952. bili održani u Celju. ${ }^{45}$ Sjedište provincijalata jedno je vrijeme, od 1936. do 1939., iz Celja preseljeno u »Škofju Loku pa opet vraćeno u Celje $\ll^{46}$, da bi kasnije, zbog teških ratnih prilika, iz Celja bilo premješteno u Split, što je »generalni ministar savjetovao tadašnjem provincijalu Mauritiusu. $\ll{ }^{47} \mathrm{U}$ to vrijeme Split je bio pod talijanskom okupacijom. Kad govorimo o upravnom aspektu Ilirske provincije male braće kapucina, radi cjelovitije slike o prilikama i neprilikama kojima je bila izložena, spomenimo riječi varaždinskog kroničara: »Od 1940. g. naime, u našoj provinciji Iliriji nije se odr-

\footnotetext{
${ }^{40}$ KSVŽ za 1941. godinu.

${ }^{41}$ Usp. SHEMATISMUS Provinciae Illyricae Ordinis fratrum minorum capucinorum, Osijek, 1942., 4.

${ }^{42}$ Isto, 15.

${ }^{43}$ KSVŽ za 1941. godinu.

${ }^{44}$ Usp. SHEMATISMUS Fratrum Minorum Capucinorum Provinciae Illyricae, Zagreb, 1958., 10.11. Na dotičnim stranicama shematizma pronalazimo kronološki popis svih provincijala Ilirske kapucinske provincije do toga vremena.

${ }^{45}$ Isto, 9.-10.

${ }^{46}$ V. ŠKAFAR, Kapucini na slovenskem v Jugoslovanski Ilirski provinci (1921-1967), 75.

${ }^{47}$ KSVŽ za 1941. godinu.
} 
žavao prov. kapitul. Zadnji kapitul bio je 1939. g. Tad je za provincijala bio izabran p. Linus koji je za godinu dana umro. Od tada pa sve do sada vrh. poglavari naše provincije dakle u roku od 12 godina bili su imenovani iz Rima. $\ll^{48}$

\section{O službama Tomislava Šagija prije izbora za provincijala 1949. - 1955.}

Tomislav Šagi, nakon upisanog i završenog teološkog studija na Katoličkom bogoslovnom fakultetu (KBF) Sveučilišta u Zagrebu (1943. - 1949.), boravio je i djelovao u hospiciju (samostanu) i župi sv. Mihaela u zagrebačkoj Dubravi. Kasnije će samostan sv. Mihaela, kad on bude izabran za provincijala, postati sjedištem Ilirske kapucinske provincije. Za prezbitera je zaređen 5. rujna 1948. godine u Zagrebu, a doktorski je rad na spomenutom Fakultetu obranio 26. 9. 1951. ${ }^{49}$ Nakon prezbiterskog ređenja fra Tomislav je kroz nekoliko godina (1949. - 1955.) paralelno obavljao i po nekoliko odgovornih službi, propovjednika, ispovjednika, a nakon 1952. godine, po povratku iz vojske, uz te će mu službe biti povjerene i druge koje će obnašati paralelno s prethodnima: magister klerika, tajnik provincije, kapelan u župi sv. Mihaela, profesor na KBF-u, pisac. Prije preuzimanja tih službi trebalo je odslužiti tzv. vojni rok. Prema evidenciji vojne knjižice ondašnje Jugoslavenske narodne armije, služenje je vojnog roka započeo i završio kao vojnik u Prilepu (Makedoniji) $\gg 18$. oktobra 1951. god., a otpušten je 18.X. 1952. $\ll{ }^{50}$ Po povratku iz vojske fra Tomislav Šagi nastavit će i dalje pisati. Iz razdoblja prije izbora za provincijala nastala su tri njegova djelca koja su plod njegovih sabranih dotadašnjih homilija. Jedno je naslovljeno Veliki znak ${ }^{51}$, drugo Dođi Gospodine ${ }^{52}$, a treće Znati i živjeti. ${ }^{53}$ Dozvolu za propovijedanje, prema tadašnjem običaju, dobio je od generalnog ministra male braće kapucina fr. Clemensa a Milwaukee krajem 1949. godine. ${ }^{54} \mathrm{Na}$ službu učitelja klerika imenovao ga je njegov prethodnik, prvi provincijal Hrvat $u$ dotadašnjoj zajedničkoj tridesetogodišnjoj povijesti provincije fra Alojzije Novak. Službu učitelja

$\overline{{ }^{48} \text { KSVŽ za 1952. godinu. }}$

${ }^{49} \mathrm{Za}$ detaljnije povijesno-biografske podatke o fra Tomislavu iz ovoga razdoblja upućujemo na studiju: A. BARIŠIĆ, Teandrička kristologija Tomislava Janka Šagi-Bunića, Zagreb, 13.-20.

${ }^{50}$ Usp. Vojnu knjižicu Jugoslovenske narodne armije Šagi Stjepana Janka, u: OATJŠB. Stjepan je bio Šagijev otac, a ime Janko bilo mu je krsno, odnosno građansko, civilno ime.

${ }^{51}$ Usp. T. ŠAGI, Veliki Znak. Deset govora o katoličkoj mariologiji, Zagreb, 1953.

${ }^{52}$ Usp. T. ŠAGI, Dođi Gospodine. Blagdanske i prigodne propovijedi, Zagreb, 1953.

${ }^{53}$ Usp. T. ŠAGI, Znati i živjeti, Zagreb, 1953.

${ }^{54}$ Vidi službeni generalov dopis odaslan iz generalne kurije u Rimu 13. rujna 1949., u: OATJŠB, fascikl Dopisi generalnog ministra ofmcap. o. dr. Šagi-Buniću. 
klerika vršio je od kraja rujna 1952., pa sve do izbora za provincijala. ${ }^{55}$ Osim učitelja klerika provincijal fra Alojzije veleučenog je doktora sv. bogoslovlja fra Tomislava, uz pristanak provincijalnog definitorija, imenovao i provincijalnim tajnikom što će ostati sve do izbora za provincijala. ${ }^{56}$ Osim ovih provincijskih službi, fra Tomislav je od rujna 1952. bio imenovan i kapelanom župe sv. Mihaela u zagrebačkoj Dubravi. Službu kapelana vršio je od 20. 9. 1952. do 12.8. 1955. ${ }^{57}$ Tako je fra Tomislav istovremeno bio propovjednik, ispovjednik, magister klerika, provincijalni tajnik, kapelan, profesor i pisac.

\section{Provincijalni kapitul Ilirske kapucinske provincije 1955. godine}

\subsection{Pripreme Za PROVINCIJALNI Kapitul, SAZIV I SUDIONICI}

Provincijal fra Alojzije Novak, prvi provincijal Hrvat u dotadašnjoj povijesti zajedničke provincije izabran na »provincijalnom kapitulu u Varaždinu 6. kolovoza $1952 . \ll^{58}$, prema propisu tada važećih Konstitucija sukladno VIII. poglavlju i 144. ${ }^{59}$ broju, uputio je tadašnjem generalnom ministru kapucinskog reda P. Benignusu a Sant Ilario Milaneseu molbu za održavanje provincijalnog kapitula u Ilirskoj kapucinskoj provinciji jer mu je trogodišnji mandat (1952. - 1955.) istjecao pa je trebalo izabrati novoga provincijala. U molbi aktualni provincijal fra Alozije predložio je da kapitul bude »Zvonko M. Pšag krajem srpnja ili početkom kolovoza $\mathrm{u}$ Varaždinu $\ll{ }^{60}$ Provincijal fra Alojzije ubrzo je od generala fr. Benignusa dobio

${ }^{55}$ Dekret provincijala fra Alozija o imenovanju fra Tomislava za službu učitelja klerika od 28. IX. 1952., Zagreb-Dubrava, pod br. 53/52. Dekret se nalazi u OATJŠB, u fasciklu: Dopisi provincijalata OFMCap. fra dr. Tomislavu Šagiju.

${ }^{56}$ Dekret provincijala fra Alozija o imenovanju fra Tomislava za službu provincijalnog tajnika datiran je 28. IX. 1952., Zagreb-Dubrava, pod br. 54/52. Dekret se nalazi u OATJŠB, u fasciklu: Dopisi provincijalata OFMCap. fra dr. Tomislavu Šagiju.

${ }^{57}$ Dekret imenovanja za župnog vikara župe sv. Mihaela izdao je tadašnji ordinarij zagrebačke nadbiskupije sede impedita dr. Fr. Salis, Zagrabiae, die 20. Septembris 1952., pod Nrus. 4554/1952. Na istom listu ispod rukom je nadopisano da je o. Tomislav Šagi, ofmcap., razriješen dužnosti vicarii cooperantis 12. VIII. 1955. Nad. Duh. Stol u Zagrebu br. 4399/55., Zagreb, 19. VIII. 1955. Niže je potpis tadašnjeg upr. ž. Zvonka M. Pšaga. Dekret se nalazi u OATJŠB.

${ }^{58}$ Vidi dopis tadašnjeg generalnog ministra male braće kapucina fr. Benignusa a San't Ilario Milanesea kojim fra Alojzija Novaka potvrđuje za provincijala, Romae, e Curia Nostra Generali die 17 Augusti 1952. Dopis se nalazi u arhivu današnje Hrvatske kapucinske provincije sv. Leopolda Bogdana Mandića koja svoje sjedište ima u istoimenom samostanu u Zagrebu (Gornja Dubrava). Za taj arhiv dalje ćemo koristiti kraticu AHKPLBM.

${ }^{59}$ Regula et Testamentum Seraphici Patris s. Francisci et Costitutiones Fratrum Minorum Capuccinorum (Editio altera), Romae, MCMXXXI, VIII. 144.

${ }^{60}$ Vidi molbu provincijala fra Alojzija generalnom ministru male braće kapucina P. Benignu pod br. 10/1955., datirana, Zagreb-Dubrava, 1. II. 1955. Vidi Molbu u: AHKPZG. 
pozitivan odgovor u kojem stoji da se $\gg$ kapitul održi 4. kolovoza 1955. godine u Varaždinu. $\ll{ }^{61} \mathrm{U}$ popratnoj poruci s ovim odgovorom generalni ministar naznačuje da će kapitulu, ako bude moguće, predsjedati netko iz Rima. Točno vrijeme zakazano za održavanje provincijalnog kapitula, kada se zapravo i održao, saznajemo iz provincijalova dopisa koji je uputio svoj braći u provinciji, kojim, kako redovničko zakonodavstvo nalaže, saziva provincijalni kapitul.

U dopisu provincijal navodi da će se provincijalni kapitul (provincialia comitia), doslovno bi bilo provincijalna skupština ili zbor, održati $\gg 19$. srpnja 1955. u našem samostanu u Varaždinu. ${ }^{62}$ Iz istog dopisa saznajemo da su se kapucinski samostani u Hrvatskoj tada nalazili u Varaždinu, Osijeku i Rijeci, a u Sloveniji u Škofjoj Loki i Sv. Križu, koji su, prema Konstitucijama, kako se navodi u dopisu, dužni »izabrati tzv. kapitularnog diskreta prema Konstitucijama br. 139. $\ll{ }^{63}$ Provincijal fra Alojzije nadalje, pozivajući se na propis Konstitucija broj 180, podsjeća svu »braću neka žarko mole za uspjeh provincijalnog kapitula ${ }^{64} \mathrm{U}$ drugom kratkom dopisu na latinskom jeziku fra Alojzije svoj braći u provinciji šalje Obavijest (Notificatio) u kojoj ih podsjeća da će prema važećem propisu Konstitucija, br. 144 i 145, na predstojećem provincijalnom kapitulu njegovi sudionici biti ova braća: »provincijal, generalni definitor, provincijalni definitori, generalni kustosi, gvardijani, i kapitularni diskreti iz samostana u Varaždinu, Škofjoj Loki, Sv. Križu, Osijeku i Rijeci, kao i provincijalni tajnik, predstojnici hospicija u Karlobagu, Mariboru i Ptuju. ${ }^{65}$ Prema glasačkoj tabeli (tabula scrutinorum) s kapitula vidljivo je da je kapitularaca ili sudionika kapitula sveukupno bilo $\gg 21$, a s pravom glasa $19 . \ll{ }^{66}$ Za predsjednika provincijalnog kapitula generalni je ministar kasnije u jednom drugom dopisu odredio fra Odilona iz Cerknice (mjesto kod Postojne u Sloveniji), tada generalnog definitora Reda male braće kapucina. ${ }^{67}$

${ }^{61}$ Dopis je generalnog ministra fr. Benignusa provincijalu fra Alojziju bez broja, Romae, die 12 mensis februarii anni 1955., vidi dopis u: AHKPZG.

${ }^{62}$ Vidi dopis naslovljen: Indicitur capitulum provinciale pod Num 34./1955., Zagreb, 12. VII. 1955., u: AHKPZG. Dopis sadrži jednu nepunu stranicu teksta.

${ }^{63}$ Vidi dopis svoj braći u provinciji provincijala fr. Alojzija naslovljen: Indicitur capitulum provinciale (Saziv provincijalnog kapitula) pod Num 34./1955., datiran, Zagreb, 12. VII. 1955., u: AHKPZG. Dopis sadrži jednu nepunu stranicu teksta.

${ }^{64}$ Isto.

${ }^{65}$ Notificatio provincijala fra Alojzija o tome koji su sve članovi skorog provincijalnog kapitula. Kratak dopis na latinskom datiran je, Zagreb, 12. VI. 1955., nema broja, u: AHKPZG.

${ }^{66}$ Usp. Scrutinia Capitoli provincialis Provinciae Illyricae O.F.M.Cap. celebrati in conventu Varaždin die 19 mensis Iulii anni 1955., sub presidentia Rev. Mi. P. Odilonis a Cerknica, u: GA, G67, VII. 1.

${ }^{67}$ Usp. Dopis generalova imenovanja fr. Odilona za predsjednika kapitula datiran u generalnoj kuriji u Rimu 8. Iulii 1955., u: AHKPZG. 


\subsection{OdRŽAVANJE PROVINCIJALNOG KAPITULA U VARAŽDINU 19. 7. 1955.}

Na provincijalnom kapitulu Ilirske kapucinske provincije, koji se održao u kapucinskom samostanu u Varaždinu 19. srpnja 1955. godine, sudionici kapitula trebaju izabrati novu provincijalnu upravu. Nisu nam poznate ostale točke jer ih među pisanom ostavštinom ne pronalazimo. U vrijeme o kojem pišemo provincijalni kapitul trajao je jedan jedini dan što će se u kasnijoj povijesti protegnuti i na nekoliko dana, praksa kakva je danas na snazi. I najvažniji zadatak provincijalnog kapitula bio je izabrati novu provincijalnu upravu ili novo vodstvo provincije koje su u to vrijeme sačinjavali provincijal, četiri definitora i dva generalna kustosa. Na ovaj kapitul mladi profesor, magister klerika i kapelan fra Tomislav Šagi došao je po pravu kao provincijalni tajnik. Nisu nam poznati svi detalji odvijanja kapitula i podrobno sve njegove faze. Ali iz onog što čitamo u kronici kapucinskog samostana u Varaždinu i onog što nam je ostavio kroničar vidljivo je da je situacija oko izbora novog provincijala bila vrlo napeta, dinamična i neizvjesna. Kroničar spominje kako je $\gg$ najveća borba bila oko osobe novog I. definitora, odnosno provincijala. $\ll{ }^{68} \mathrm{Ta}$ kođer spominje kako je svaka strana, i hrvatska i slovenska, imala svoga kandidata. Kandidat za slovensku stranu bio je fra Rudolphus ab Hajdina (fra Rudolf iz Hajdine), dotadašnji definitor, a za hrvatsku fra Tomislav Šagi. Fra Rudolf, prema Shematizmu iz 1942. godine, $\gg$ rođen je 6. Nov. 1913., a za prezbitera je zaređen 20. Dec. 1936. $\ll{ }^{69}$ Od svoga protukandidata za provincijala fra Tomislava, koji je rođen 2. veljače 1923., bio je, dakle, stariji pa prema tome i iskusniji za deset godina života. Kroničar kapucinskog samostana u Varaždinu prenosi nam podatak da je sveukupno kapitularaca koji su glasovali $\gg$ na kapitulu bilo $17 \mathrm{~s}$ time da se predsjednik kapitula dr. o. Odilo uzdržao od glasovanja $\ll .{ }^{70}$ Prema tome, za valjan izbor za provincijala, prema Konstitucijama broj 135, pobjedniku je trebala natpolovična većina prisutnih kapitularaca kad se isključe nevaljani glasovi. Opet prema Konstitucijama sada broja 134, biranje se za provincijala obavljalo tajnim glasovanjem da se nikada ne saznaju imena birača. Konstitucije br. 136 propisivale su pak da je prikladan kandidat za provincijala onaj koji je po prvim zavjetima barem deset godina član Reda male braće kapucina i da mora imati minimalno trideset godina života. Jednako tako Konstitucije u istom broju preporučuju da braća moraju izabrati onoga kojeg se drži boljim za dotičnu službu i sposobnijim te da se svaki drugi obzir mora odbaciti. U broju 137 Konstitucije propisuju i moralne kvalitete

\footnotetext{
${ }^{68}$ Usp. KSVŽ za 1955. godinu.

${ }^{69}$ Usp. SHEMATISMUS Provinciae Illyricae Ordinis fratrum minorum capucinorum, Osijek, 1942., 10.

${ }^{70}$ Usp. KSVŽ za 1955. godinu.
} 
koje moraju krasiti poglavara koji druge treba nadilaziti u razboritosti, pobožnosti, znanju i revnosti za redovničku stegu.

\subsection{Fra Tomislav Šagi iZabran Za ProvinciJala ILIRSKE KAPUCINSKE PROVINCIJE}

Upravo netom spomenute vrline koje su tražile kapucinske Konstitucije za višeg poglavara prepoznate su u tada najmlađem kandidatu za provincijala u povijesti Ilirske kapucinske provincije, u fra Tomislavu Šagiju. Prije samog izbora za provincijalnog ministra ili provincijala predsjednik kapitula fra Odilon, bilježi nam varaždinski kroničar, upozorio je na ovo: »Ako je provincijal Hrvat, I. def. mora biti Slovenac, II. def. Hrv., III. def. Slovenac, a IV. Hrvat. I. Custos Slov., a drugi Hrvat. Provincijalu tajnik u tom slučaju mora biti Slovenac. Ako je pak provincijal Slovenac, onda: I. def. Hrvat, II. Slov., III. Hrvat, IV., Slovenac. I Custos Hrvat, II. Slov., a prov. tajnik Hrvat.« Iz te sheme koju nam donosi kroničar, koja inače nema nikakvo utemeljenje ni u kakvom tadašnjem zakonodavstvu kapucinskog reda ili provincije, a koju je odredio tada predsjednik kapitula i generalni definitor slovenac fra Odilon, već je vidljivo kako bi mogla izgledati nova provincijalna uprava s obzirom na nacionalnu raspodjelu i zastupljenost u njoj.

Prema Kronici kapucinskog samostana u Varaždinu vidljivo je da je izbor novog provincijala bio napet, dinamičan i do samog kraja neizvjestan. Zbog podjednakosti glasova kroničar spomenutog samostana bilježi da je došlo »do četvrtog glasovanja (i za I. def. i) za provincijala. $\ll^{71}$ Iz tabele u kojoj su zabilježena sva glasovanja vidljivo je da je u svim krugovima glasovanja fra Tomislav Šagi dobio $\gg$ po 9 glasova dok je fra Rudolf iz Hajdine, u prvom krugu dobio 6, a u ostalima po $8 . \ll^{72}$ Iz tabele je vidljivo, što odudara od Kronike, da je bilo tri kruga glasovanja, a ne četiri. U svakom slučaju dinamike i neizvjesnosti nije nedostajalo. Tako je dotadašnji mladi kapelan, magister klerika, provincijalni tajnik, profesor i pisac postao provincijal Ilirske kapucinske provincije na provincijalnom kapitulu održanom u Varaždinu 19. srpnja 1955. godine. U trenutku kad je bio izabran, fra Tomislav bio je najmlađi provincijal u povijesti Ilirske kapucinske provincije, i do tada, a i kasnije. Novoizabrani provincijal fra Tomislav Šagi nalazio se tada u 32. godini života. Svih dotadašnjih deset provincijala dvojezične i dvonacionalne Ilirske kapucinske provincije, od njezina osnutka do tada, pa i kasnije, bili su po dobi i iskustvu života znatno stariji od novoizabranog provincijala. Uvidom u sačuvane shematizme Ilirske kapucinske

\footnotetext{
${ }^{71}$ Usp. isto.

${ }^{72}$ Usp. Scrutinia Capitoli provincialis Provinciae Illyricae O.F.M.Cap. celebrati in conventu Varaždin die 19 mensis Iulii anni 1955., sub presidentia Rev. Mi. P. Odilonis a Cerknica, u: GA, G67, VII. 1.
} 
provincije iz 1925., 1942. i 1958. godine, te one iz kasnijih godina, to lako možemo otkriti i potvrditi.

S obzirom na redovničku i kapucinsku tradiciju prema kojoj se do tada u Ilirskoj kapucinskoj provinciji, kakav je uostalom bio običaj i po drugim provincijama i kod drugih redovnika, na tako odgovorno mjesto pretežno biralo starije i iskusnije fratre, možemo pretpostaviti da je dotada najmlađi provincijal morao osjećati određeni pritisak. Nije samo riječ o pritisku koji bi dolazio iz prethodne tradicije već $\mathrm{i}$ onom koji je mogao doći od njegovih novih suradnika, provincijalnih definitora i kustosa, koji su izabrani na kapitulu kao dio provincijalne uprave, a koji su bili poprilično stariji od njega. Novu provincijalnu upravu s mladim provincijalom na čelu činili su provincijalni definitori: $\gg$ A. R. P. Rudolfus ab Hajdina (I), A. R. P. Ignacius a Vidovec (II), A. R. P. Augustinus a Sovodnje (III), A. R. P. Maximilianus a Vidovec (IV) $\ll^{73}$ Za generalne kustose bili su izabrani: $\gg$ A. R. P. Vigilius a sv. Vid (I), A. R. P. Hadrianus a Radovec (II). $\ll^{74}$

Novoizabrani provincijal fra Tomislav Šagi bio je dakle ne samo najmlađi izabrani provincijal u povijesti Ilirske kapucinske provincije nego je bio i mlađi, od nekih gotovo i deset godina, od svih novoizabranih mu najbližih suradnika, definitora čija je dužnost bila da mu pomažu u upravi provincije u narednom trogodištu. Generalni ministar kapucinskog reda fr. Benignus a Sant'Ilario Milanese potvrdio je izbor novoizabranog provincijala fra Tomislava Šagija i novu provincijalnu upravu na mandat od tri godine. ${ }^{75}$ Novoizabrani će provincijal nastaviti voditi Ilirsku kapucinsku provinciju iz Zagreba. Sjedište provincijalata, još od njegova prethodnika fra Alojzija, bit će, nakon Celja, Škofje Loke i Splita, i za vrijeme njegove provincijalne službe u hospiciju (samostanu) svetog Mihaela u Zagrebu na tadašnjoj adresi Bihaćka 51, danas Kapucinska ulica 47.

\section{Zaključak}

Ono što smo u sklopu naše zadane teme istražili na temelju dosad neistraženih i neistraživanih arhivskih izvornih dokumenata kao prilog proučavanju Ilirske kapucinske provincije o 50. obljetnici njezina ukinuća i istovremeno nastanka samostalnih provincijalnih komisarijata, odnosno provincija (1967. - 2017.), hrvatske i slovenske, pokazalo nam je dinamiku i okvir povijesnih, društvenih i redovničkih

\footnotetext{
${ }^{73}$ Usp. Scrutinia Capitoli provincialis Provinciae Illyricae O.F.M.Cap. celebrati in conventu Varaždin die 19 mensis Iulii anni 1955., sub presidentia Rev. Mi. P. Odilonis a Cerknica, u: GA, G67, VII. 1.

${ }^{74}$ Usp. isto.

${ }^{75}$ Usp. Dopis generalnog ministra kapucinskog reda fr. Benignusa a Sant'Ilaria Milanesea kojim potvrđuje izbor za provincijala fra Tomislava Sagija, Romae, in Curia Nostra Generali, die 23 Iulii 1955., u: AHKPZG.
} 
procesa koji su se odvijali prije i za vrijeme izbora fra Tomislava Šagija za provincijala Ilirske kapucinske provincije, a izabran je na provincijalnom kapitulu u kapucinskom samostanu, u Varaždinu, 19. 7. 1955. godine. Osim spomenutih procesa upoznali smo se ukratko i s dinamikom, tradicijom kapucinskog Reda i poviješću odnosa kakvi su bili unutar zajedničke dvonacionalne i dvojezične provincije zvane Ilirska, koja je bila sastavljena od fratara kapucina Hrvata i Slovenaca. Sve nam je to poslužilo kao korisna pretpostavka koja nas je dalje vodila prema istraživanju, otkrivanju i razumijevanju procesa, postupka i puta samog izbora fra Tomislava Śagija kao najmlađeg provincijala u sveukupnoj povijesti Ilirske provincije male braće kapucina, koja je kao takva postojala od 1921. do 1967. godine. Zaključno, recimo da ni vanjske (društveno-političke) ni unutarnje okolnosti (dotadašnja tradicija Ilirske kapucinske provincije) nisu išle u prilog tome da tada vrlo mlad i još uvijek s vrlo malo iskustva kao profesor, pisac, kapelan, provincijski tajnik i magister klerika fra Tomislav bude izabran za najodgovorniju osobu u provinciji, za provincijala. Upravo zato i usprkos svemu taj je izbor potvrdio njegovu zrelost i ozbiljnost što je bilo neophodno za obnašanje prije svega teške i odgovorne provincijalne službe. 


\title{
THE ILLYRIAN CAPUCHIN PROVINCE AND THE ROAD TO THE ELECTION OF TOMISLAV ŠAGI FOR THE PROVINCIAL IN 1955
}

\author{
Anto BARIŠIĆ*
}

Summary: The paper explores and presents the Illyrian Capuchin Province together with the election of Tomislav Šagi as the Provincial, as well as what had preceded that election. To this end, the paper brings a brief overview of the historical socio-political and ecclesiastical-religious framework within which the Province operated and within which the election of Tomislav Šagi, the Capuchin Franciscan, for the Provincal of the Illyrian Capuchin Province, took place in July 1955. After a brief familiarization with the external, non-ecclesiastical circumstances of the society at the time and with the preventive arrest of Tomislav Šagi by the civil authorities, there is a general overview and familiarization with the Illyrian Capuchin Province from a historical, statistical, and administrative point of view. This is followed by a brief description of the positions Fr. Tomislav Šagi held before the provincial elections, from 1949 to 1955. In the end, we explore the preparations for the Provincial Chapter and its session, and we present the results of the Provincial Chapter held on July 19, 1955, in the OFM Capuchin monastery in Varaždin, where Tomislav Šagi was elected as the Provincial of Illyrian Capuchin Province. The motive for researching the given and previously unexplored topic is the $50^{\text {th }}$ anniversary of the abolition (1967 - 2017) of the former binational and bilingual Capuchin province called Illyrian, composed of Croatian and Slovenian friars, while the author used exclusively previously unresearched archival original documents.

Keywords: Illyrian Capuchin Province, the Provincial, Chapter, Fr. Tomislav Šagi.

\footnotetext{
* Asst. Prof. Anto Barišić, Catholic Faculty of Theology, University of Zagreb, Vlaška 38, 10000 Zagreb, Croatia, anto@kapucini.hr
} 